\title{
PENGARUH GAYA KEPEMIMPINAN, LINGKUNGAN KERJA DAN KOMPENSASI TERHADAP KOMITMEN ORGANISASI (Studi Kasus di Universitas Suryadarma)
}

\author{
Rita Intan Permatasari \\ farrelaira@gmail.com
}

\begin{abstract}
ABSTRAK
Pendidikan sebagai sarana mencerdaskan kehidupan bangsa menjadi sektor penting dalam memberikan kontribusi pengembangan sumber daya manusia yang bermutu, berkualifikasi, ahli, terampil, kreatif dan inovatif. Perguruan tinggi menjadi salah satu lembaga pendidikan secara formal diserahi tugas dan tanggung jawab mempersiapkan sumber daya manusia tersebut. Komitmen seorang dosen menjadi penting dalam rangka mewujudkan Tri Dharma perguruan Tinggi yang berkualitas.

Faktor-faktor yang dapat mempengaruhi keberpihakan atau komitmen seseorang terhadap organisasinya antara lain gaya kepemimpinan, lingkungan kerja dan kompensasi yang diterima.

Dalam penelitian ini terdapat empat variabel, yaitu komitmen organisasi (Y) sebagai variabel terikat, gaya kepemimpinan (X1), lingkungan kerja (X2) dan kompensasi (X3) masing-masing sebagai variabel bebas. Lokasi penelitian adalah Universitas Suryadarma, Jakarta. Responden merupakan dosen tetap sebanyak 60 responden, dimana pengambilan sampel dengan pendekatan simple random sampling. Pengumpulan data dengan melakukan penyebaran kuesioner. Metode analisis data dengan menggunakan alat statistik metode analisis regresi berganda, dengan bantuan SPSS dalam pengolahan datanya.

Hasil penelitian ini adalah variabel - variabel bebas, yaitu gaya kepemimpinan (X1), lingkungan kerja (X2) dan kompensasi (X3) berpengaruh secara signifikan dan searah terhadap variabel terikat yaitu komitmen organisasi (Y) di Universitas Suryadarma Jakarta, baik secara parsial maupun simultan. Sedangkan hasil hipotesis menunjukkan bahwa seluruh Ho di tolak dan $H_{1}$ diterima, baik hipotesis secara parsial maupun hipotesis secara simultan. Sedangkan variabel bebas mampu menjelaskan variabel terikat sebesar $88,6 \%$, sedangkan sisanya sebesar $11,4 \%$ dijelaskan oleh variabel lain yang tidak dibahas dalam penelitian ini.
\end{abstract}

\section{PENDAHULUAN}

\section{Latar belakang}

Pendidikan sebagai sarana untuk mencerdaskan kehidupan bangsa sebagaimana tertuang dalam tujuan pendidikan nasional menjadi sektor yang sangat penting memberikan kontribusi dalam mengembangkan sumber daya manusia yang bermutu, yang berkualifikasi, ahli, terampil, kreatif dan inovatif. Oleh karena itu pendidikan harus ditangani secara sungguh-sungguh oleh semua pihak, terutama oleh pemerintah selaku pembuat kebijakan.

Perguruan tinggi merupakan salah satu lembaga pendidikan yang secara formal diserahi tugas dan tanggung jawab 
mempersiapkan mahasiswa sesuai dengan tujuan pendidikan nasional, yaitu mengisi kebutuhan masyarakat akan tersedianya tenaga ahli dan tenaga terampil dengan tingkat dan jenis kemampuan yang sangat beragam.

Universitas Suryadarma sebagai lembaga pendidikan yang telah berdiri selama 26 tahun berupaya untuk meningkatkan kualitas para pengajarnya. Di perguruan tinggi, seorang dosen memegang peran sangat penting bagi kemajuan institusinya. Kesadaran ini ditunjukkan oleh upaya-upaya pribadi untuk menjadikan dirinya memiliki kompetensi dan kepakaran yang sesuai dengan minat dan bidang yang ditekuni. Dosen adalah pendidik profesional dan ilmuwan dengan tugas utama mentransformasikan, mengembangkan, dan menyebarkan ilmu pengetahuan, teknologi dan seni melalui pendidikan, penelitian dan pengabdian kepada masyarakat.

Banyak faktor yang dapat mempengaruhi prestasi kerja dosen sebagai karyawan pada suatu organisasi, diantaranya adalah komitmen organisasi. Sebagaimana diungkapkan oleh Robbins dan Judge (2007) bahwa komitmen organisasi didefinisikan sebagai keadaan dimana pegawai berpihak pada organisasi tertentu dan tujuannya, serta keinginannya untuk mempertahankan keanggotaannya dalam organisasi
Organizational commitment is defined as a state in which an employee identifies with a particular organization and its goals and wishes to maintain membership in the organization). Dengan demikian, komitmen organisasi yang tinggi berarti terdapat keberpihakan kepada organisasi yang tinggi pula. Komitmen sebagai prediktor kinerja seseorang merupakan prediktor yang lebih baik dan bersifat global, dan bertahan dalam organisasi sebagai suatu keseluruhan bukan kepuasan kerja semata. Komitmen membuat seseorang memiliki keterkaitan emosional dalam organisasi sehingga individu tersebut melakukan identifikasi nilai maupun aktivitas organisasi, sehingga dirinya akan semakin terlibat dengan apa yang dilakukan oleh organisasi. Dosen sebagai ujung tombak suatu perguruan tinggi memerlukan umpan balik dari lembaga atas hasil kerja mereka sebagai panduan bagi perilaku mereka di masa yang akan datang.

Elemen-elemen organisasi seperti gaya kepemimpinan, lingkungan kerja, kompensasi, dan komitmen organisasi merupakan satu kesatuan yang tidak dapat berdiri sendiri, melainkan secara bersamasama ikut memberikan kontribusi pada pencapaian keunggulan kompetitif yang pada akhirnya akan membantu pencapaian tujuan utama organisasi yaitu kinerja organisasi yang tinggi. 
Lalu benarkah komitmen organisasi itu dapat dipengaruhi oleh gaya kepemimpinan, lingkungan kerja dan kompensasi yang berlaku di lingkungan Universitas Suryadarma. Inilah permasalahan yang menarik untuk dikaji lebih lanjut dalam penelitian ini yang berjudul

"Pengaruh

Gaya

Kepemimpinan, Lingkungan Kerja dan Kompensasi terhadap Komitmen Organisasi (Studi Kasus di Universitas Suryadarma) “

\section{Perumusan Masalah}

Berdasarkan latar belakang yang telah diuraikan di atas, maka rumusan masalah yang akan diuji lebih lanjut dalam penelitian ini adalah:

1. Apakah gaya kepemimpinan berpengaruh positif dan signifikan terhadap komitmen organisasi ?

2. Apakah lingkungan kerja berpengaruh positif dan signifikan terhadap komitmen organisasi ?

3. Apakah kompensasi berpengaruh positif dan signifikan terhadap komitmen organisasi ?

4. Apakah gaya kepemimpinan, lingkungan kerja dan kompensasi secara bersama-sama berpengaruh positif dan signifikan terhadap komitmen organisasi ?

\section{Pembatasan Masalah}

Banyak faktor yang mempengaruhi komitmen organisasi, namun dalam penelitian ini faktor penyebab yang akan diteliti dibatasi pada gaya kepemimpinan, lingkungan kerja, dan kompensasi pada komitmen dosen tetap Universitas Suryadarma.

\section{Tujuan Penelitian}

Adapun tujuan dari penelitian ini adalah :

1. Untuk mengetahui seberapa besar pengaruh gaya kepemimpinan, lingkungan kerja dan kompensasi secara parsial terhadap komitmen organisasi di Universitas Suryadarma .

2. Untuk mengetahui seberapa besar pengaruh gaya kepemimpinan, lingkungan kerja dan kompensasi secara bersama-sama (simultan) terhadap komitmen dosen tetap Universitas Suryadarma

\section{Kegunaan Penelitian}

Penelitian ini diharapkan dapat memberikan manfaat yang positif baik secara teoritis maupun praktis.

1. Secara teoritis, hasil penelitian diharapkan dapat menambah khasanah ilmu pengetahuan dan informasi kepada peneliti di bidang sumber daya manusia khususnya mengenai pengaruh gaya kepemimpinan, lingkungan kerja dan kompensasi terhadap komitmen organisasi. 
2. Secara praktis, hasil penelitian ini kiranya dapat diterima sebagai masukan yang berguna dan tambahan informasi kepada universitas dalam rangka pembinaan dan pengembangan kinerja para dosen tetap lebih lanjut, memanfaatkan sebagai alat evaluasi diri mengenai faktor-faktor yang dapat meningkatkan komitmen organisasi dan memanfaatkan sebagai bahan kajian lebih lanjut mengenai variabel-variabel yang berpengaruh langsung maupun tidak langsung terhadap komitmen organisasi.

\section{TINJAUAN PUSTAKA}

\section{Komitmen Organisasi}

Komitmen organisasi pada hakikatnya adalah sampai tingkat mana seseorang pegawai memihak pada suatu organisasi tertentu dan tujuan-tujuannya, serta berniat memelihara keanggotaan dalam organisasi itu. Sebagaimana diungkapkan oleh Robbins dan Judge (2007) bahwa komitmen organisasi didefinisikan sebagai keadaan di mana pegawai berpihak pada organisasi tertentu dan tujuannya, serta keinginannya untuk mempertahankan keanggotaannya dalam organisasi (Organizational commitment is defined as a state in which an employee identifies with a particular organization and its goals and wishes to maintain membership in the organization).
Pendapat lain menyatakan bahwa komitmen organisasi tidak sekedar keberpihakan dan keterlibatan dalam kegiatan organisasi, namun juga kesetiaan yang diungkapkan pegawai terhadap perusahaannya. Sebagaimana diungkapkan Ivancevich, Konopaske, dan Matteson (2008), komitmen organisasi adalah rasa kesediaan, keterlibatan, dan loyalitas yang diungkapkan oleh pegawai terhadap perusahaannya (Organizational commitment is a sense of identification, involvement, and loyalty expressed by an employee toward the company).

Berdasarkan uraian di atas, yang dimaksud dengan komitmen organisasi adalah keberpihakan seseorang sebagai anggota organisasi terhadap organisasinya dengan berperan aktif dalam rangka mencapai tujuan dan keinginannya untuk tetap menjadi anggota organisasi, dengan indikator : 1) keinginan kuat untuk tetap menjadi anggota organisasi; 2) kemauan kuat untuk berusaha sesuai dengan tujuan organisasi; 3) penerimaan nilai-nilai dan tujuan organisasi; dan 4) kesetiaan terhadap organisasi.

\section{Gaya Kepemimpinan}

Campling, et al., (2002) menyatakan bahwa gaya kepemimpinan merupakan pola pendekatan yang ditunjukkan oleh seorang pemimpin (leadership style is the recurring pattern of behaviours exhibited by a leader). Dengan kata lain, pendekatan 
pemimpin menunjukkan gaya kepemimpinannya.

Gaya kepemimpinan adalah pola pendekatan pemimpin yang spesifik merupakan karakteristik dirinya dalam mengarahkan bawahannya baik secara individu maupun kelompok dalam mencapai tujuan organisasi, dengan indikator : 1) tingkat kepercayaan diri; 2) respek bawahan; 3) kepiawaian dalam mengarahkan; 4) keterbukaan dalam pengambilan keputusan ; 5) keluwesan dalam berkomunikasi; dan 6) akuntabilitas terhadap semua kebijakan yang dilakukan. Menurut Reddin sebagaimana dikutip oleh Thoha, gaya kepemimpinan dibedakan menjadi gaya yang efektif dan gaya yang tidak efektif. Gaya kepemimpinan yang efektif terdiri atas : 1) pelaksana (executive); 2) pecinta pengembang (developer); 3) otokratis yang baik hati (benevolent autocraf); 4) birokrat (bereaucraf). Lebih lanjut dijelaskan sebagai berikut . 1) Pelaksana (executive).

Sedangkan gaya kepemimpinan yang tidak efektif terdiri dari : 1) pecinta kompromi ( compromiser ); 2) pelindung atau penyelamat (missionary); 3) otokratis (autocraft); dan 4) lari dari tugas (deserter).

Uraian di atas menunjukkan bahwa gaya setiap pemimpin berbeda-beda. Demikian juga dengan para pengikutnya. Ini merupakan cara lain untuk mengatakan bahwa situasi-situasi tertentu menuntut satu gaya kepemimpinan tertentu, sedangkan situasi lainnya menuntut gaya yang lain pula. Pemimpin berbeda satu sama lain. Pada suatu waktu tertentu kebutuhankebutuhan kepemimpinan dari suatu organisasi mungkin berbeda dengan waktu lainnya. Gaya kepemimpinan adalah pola pendekatan pemimpin yang spesifik merupakan karakteristik dirinya dalam mengarahkan bawahannya baik secara individu maupun kelompok dalam mencapai tujuan organisasi, dengan indikator : 1) tingkat kepercayaan diri; 2) respek bawahan; 3) kepiawaian dalam mengarahkan; 4) keterbukaan dalam pengambilan keputusan ; 5) keluwesan dalam berkomunikasi; dan 6) akuntabilitas terhadap semua kebijakan yang dilakukan.

\section{Lingkungan Kerja}

Lingkungan kerja adalah tempat di mana pegawai melakukan aktivitas setiap harinya. Lingkungan kerja yang kondusif memberikan rasa aman dan memungkinkan pagawai untuk dapat bekerja optimal. Lingkungan kerja dapat mempengaruhi emosional pegawai. Jika pegawai menyenangi lingkungan kerja dimana dia bekerja, maka pegawai tersebut akan betah di tempat kerjanya, melakukan aktifitasnya sehingga waktu kerja dipergunakan secara efektif. Produktivitas akan tinggi dan otomatis prestasi kerja pegawai juga tinggi. Lingkungan kerja itu mencakup hubungan antara bawahan dan 
atasan serta lingkungan fisik tempat pegawai bekerja.

Bentuk lingkungan kerja itu sendiri terbagi dua yaitu, 1) Lingkungan kerja yang bersifat materiil yaitu lingkungan yang tersedia pada perusahaan dalam upaya peningkatan kinerja dan 2) lingkungan kerja yang bersifat non materiil yaitu lingkungan dimana terjalin hubungan kerja yang harmonis antara sesama karyawan, karyawan dengan atasan atau sebaliknya serta karyawan dengan pemilik perusahaan.

Sebagaimana diungkapkan Suma'mur PK (2008), banyak faktor yang berpengaruh pada pembentuan suatu lingkungan kerja yang terkait dengan kemampuan manusia sebagai pekerja. Faktor yang dimaksud antara lain : (a) faktor fisik, meliputi ruang kerja, penerangan, suhu udara, kelembaban, suara dan tekanan udara (b) faktor kimia seperti gas, uap , debu, dan sebagainya (c) faktor biologis seperti konstruksi, isi kantor dan cara kerja (e) faktor mental-psikologis, seperti suasana kerja, hubungan kerja antar pekerja atau dengan pengusaha, pemilihan kerja.

Untuk pengajaran dosen di kampus, faktor yang banyak berpengaruh adalah faktor fisik, mental psikologis, sosial ekonomi. Faktor lingkungan fisik di kampus juga merupakan penunjang kinerja dosen dalam proses pengajarannya seperti ruang kelas yang nyaman, perpustakaan yang memadai, laboratorium yang canggih, studio yang memenuhi syarat serta media pengajaran yang menunjang. Faktor lingkungan mental psikologis dosen adalah hubungan interpersonal dengan koordinasi yang baik di dalam struktur organisasi perguruan tinggi. Faktor sosial ekonomi seperti organisasi profesi, kepedulian terhadap kondisi fisik dosen, pengembangan kampus, deregulasi dari peraturan, situasi dan kondisi keuangan, inflasi.

Lingkungan kerja yang menimbulkan ketidakpuasan yang tidak nampak tetapi dapat dirasakan pekerja antara lain : kondisi pekerjaan, hubungan kerja, status, gaji, dan rasa aman. Semua itu termasuk kelompok non fisik. Kondisi pekerjaan menggambarkan suasana di tempat kerja masing-masing, termasuk hubungan kerja dengan sesama pekerja maupun pada pimpinan di tempat bekerja. Dari kondisi pekerjaan, timbul kesan-kesan yang dirasakan pekerja selama bekerja di tempat tersebut. Selanjutnya status, serta gaji untuk kebutuhan hidup, rasa aman di tempat kerja termasuk dalam kategori ini. Sebuah lingkungan yang didesain dengan baik, tidak hanya kondusif tetapi juga memberika suasana yang umumnya menyenangkan dan tidak menyenangkan pada aktivitas yang sedang berlangsung. Konsekuensinya, organisasi perlu meningkatkan perhatiannya pada desain dan pengawasan atas faktor-faktor lingkungan seperti suara, debu, 
penerangan, suhu, kelembaban polusi. Suhu yang ekstrim, kelembaban, debu dan kotoran mempunyai pengaruh yang nyata untuk efisiensi kerja. Demikian pula halnya dengan tingkat penerangan pencahayaan yang harus disediakan, sehingga para pekerja bisa melakukan pekerjaan tanpa harus memicingkan mata. Makin detail pekerjaannya, makin membutuhkan cahaya.

Kondisi lingkungan kampus yang terpelihara baik secara fisik maupun secara psikologis melalui hubungan antar sesama dosen, pimpinan dan karyawan beserta seluruh staf manajemen kampus juga akan meningkatkan kinerja dosen. Kesesuaian lingkungan fisik dan psikologis akan mendorong kinerja dosen lebih meningkat. Ini berarti akan membawa dampak kepada keberhasilan pendidikan tinggi di dalam proses belajar mengajar di perguruan tingginya.

Berdasarkan uraian di atas maka dapat disintesakan bahwa lingkungan kerja adalah segala sesuatu yang ada di sekitar para pekerja dan yang dapat mempengaruhi dirinya dalam menjalankan tugas-tugas di dalam mencapai tujuan organisasi yang ditunjukkan dalam dua dimensi, pertama lingkungan fisik dengan indikator : (1) kenyamanan ruangan, (2) kelengkapan peralatan kerja, (3) kelengkapan alat telekomunikasi dan informasi, dan kedua lingkungan sosial/psikologis dengan indikator : (1) kenyamanan suasana kerja, (2) kualitas hubungan atasan dan bawahan, (3) hubungan antar sesama pegawai.

\section{Kompensasi}

Dalam suatu organisasi, pemberian kompensasi merupakan faktor penting untuk dapat menarik, memelihara, mempertahankan sumber daya manusia bagi kepentingan organisasi. Menurut Veithzal Rivai dan Ella Jauvani Segala (2009), kompensasi merupakan sesuatu yang diterima karyawan sebagai pengganti kontribusi jasa mereka pada perusahaan. Pemberian kompensasi merupakan salah satu pelaksanaan fungsi manajemen sumber daya manusia yang berhubungan dengan semua jenis pemberian penghargaan individual sebagai pertukaran dalam melaksanakan tugas keorganisasian. Kompensasi merupakan biaya utama atas keahlian atau pekerjaan dan kesetiaan dalam bisnis perusahaan pada abad ke 21 ini. Kompensasi menjadi alasan utama mengapa kebanyakan orang mencari pekerjaan.

Pada umumnya, kompensasi diberikan untuk menarik karyawan yang cakap masuk ke dalam organisasi, mendorong mereka untuk berprestasi tinggi, mempertahankan karyawan yang produktif dan berkualitas agar tetap setia. 
Jika dikelola dengan baik, kompensasi akan membantu perusahaan untuk mencapai tujuan dan memperoleh, memelihara, dan menjaga karyawan dengan baik. Sebaliknya, tanpa kompensasi yang cukup, karyawan yang ada mungkin untuk meninggalkan perusahaan dan untuk melakukan penempatan kembali tidaklah mudah. Akibat dari ketidakpuasan dalam pembayaran yang dirasa kurang akan mengurangi kinerja, meningkatkan keluhan-keluhan, menyebakan mogok kerja dan mengarah pada tindakantindakan fisik dan psikologis, seperti meningkatnya ketidakhadiran dan perputaran karyawan, yang pada gilirannya akan menurunkan kesehatan jiwa karyawan yang semakin parah. Sebaliknya, jika terjadi kelebihan pembayaran, juga akan menyebabkan perusahaan dan individual kurang daya kompetisinya dan menimbulkan kegelisahan, perasaan bersalah dan suasana yang tidak nyaman dikalangan karyawan.

Menurut Kinicki dan William (2009), kompensasi menjadi tiga bagian, yaitu : (1) gaji atau upah, (2) insentif, dan (3) manfaat lainnya. Selanjutnya secara garis besar kompensasi dibedakan menjadi dua kelompok yaitu : kompensasi finansial dan kompensasi bukan finansial.

Dapat dipahami bahwa kompensasi finansial ada yang langsung ( direct compensation ) berupa gaji, upah atau insentif dan ada yang tidak langsung (indirect compensation atau employee welfare atau kesejahteraan karyawan). Gaji adalah imbalan finansial yang dibayarkan kepada karyawan secara teratur, seperti tahunan, caturwulan, bulanan, atau mingguan. Gaji merupakan jenis penghargaan yang paling penting dalam organisasi. Upah merupakan imbalan finansial langsung yang dibayarkan kepada para pekerja berdasarkan jam kerja, jumlah barang yang dihasilkan atau banyaknya pelayanan yang diberikan. Upah tidak seperti gaji yang jumlahnya relatif tetap, besarnya upah dapat berubah-ubah.

Insentif merupakan imbalan langsung yang dibayarkan kepada karyawan karena kinerjanya melebihi standar yang ditentukan. Dengan mengasumsikan bahwa uang dapat digunakan untuk mendorong karyawan bekerja lebih giat lagi, maka mereka yang produktif lebih menyukai gajinya dibayarkan berdasarkan hasil kerja.

Kompensasi berbentuk uang, artinya kompensasi dibayar dengan sejumlah uang kartal kepada karyawan bersangkutan. Sedangkan kompensasi berbentuk barang, misalnya kompensasi dibayar $10 \%$ dari produk yang dihasilkan.

Sedangkan kompensasi non finansial dapat berupa pekerjaan dan lingkungan pekerjaan. Kompensasi tidak langsung (fringe benefit) merupakan kompensasi tambahan yang diberikan bedasarkan 
kebijaksanaan perusahaan terhadap semua karyawan dalam usaha meningkatkan kesejahteraan para karyawan. Contonya asuransi kesehatan, asuransi jiwa, dan bantuan perumahan.

Berdasarkan deskripsi konsep dari berbagai ahli tentang kompensasi maka dapat disintesakan kompensasi adalah imbalan yang dperoleh seseorang baik berupa finansial maupun non finansial sebagai hasil dari pelaksanaan tugas/pekerjaannnya, dengan indikator : (1) honor/upah, (2) tunjangan (3) bonus (4) penghargaan dan (5) jenjang karir.

\section{METODOLOGI PENELITIAN}

Tempat dan Waktu Penelitian

1. Tempat Penelitian

Kegiatan penelitian ini dilaksanakan di Universitas Suryadarma, Jakarta.

2. Waktu penelitian

Penelitian dilakukan sejak bulan Maret Sampai dengan Desember 2015.

\section{Populasi dan Sampel}

Populasi

Populasi penelitian adalah seluruh dosen tetap di Universitas Suryadarma sebanyak 100 orang.

Sampel

Sampel yang diambil dalam penelitian ini dilaksanakan secara acak (Simple Random Sampling). Dalam penelitian ini diambil sampel sebanyak 80 orang dosen sebagai responden.
Dari jumlah populasi yang ada, maka ukuran sampel dalam penelitian ini ditetapkan dengan menggunakan rumus Slovin, yaitu :

$$
\begin{gathered}
n=\frac{\mathrm{N}}{1+\mathrm{N}\left(\mathrm{e}^{2}\right)} \\
n=\begin{array}{c}
100 \\
1+100\left(0,05^{2}\right) \\
n=80
\end{array}
\end{gathered}
$$

\section{Metode Pengumpulan Data}

Metode penelitian yang akan digunakan adalah metode survei dengan teknik korelasional, yakni dengan cara pengumpulan data melalui instrumen dan dengan teknik path analysis yakni untuk melihat pengaruh langsung atu tidak langsung di antara variabel. Dalam penelitian ini terdapat tiga variabel bebas, yaitu gaya kepemimpinan, lingkungan kerja, dan kompensasi serta satu variabel terikat yaitu komitmen organisasi. Pengaruh antara variabel bebas dan variabel terikat penelitian ini dapat digambarkan dalam bentuk konstelasi pengaruh antara variabel, sebagaimana pada gambar berikut : 


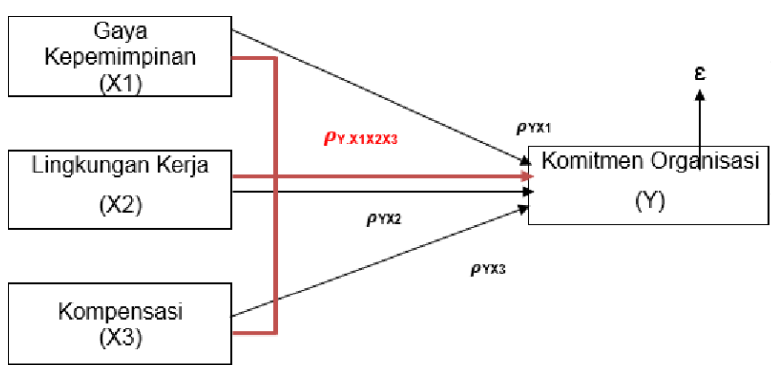

Gambar 2.4

Konstelasi Masalah Penelitian

Ada empat jenis data atau variabel yang dijaring dengan menggunakan kuisioner dengan skala penilaian terhadap pertanyaan dengan jawaban yang berskala likert. Keabsahan dan kehandalan tiap butir pertanyaan dilakukan uji validitas dan uji reliabilitas.

\section{Teknik Analisis Data}

Teknik analisis data yang digunakan adalah teknik analisis data secara deskriptif dan inferensial. Penggunaan teknik data secara deskriptif digunakan dalam hal penyajian data, ukuran sentral, dan ukuran penyebaran. Sedangkan, analisis inferensial digunakan untuk menguji hipotesis dengan menggunakan analisis jalur (path analysis). Semua pengujian hipotesis dilakukan dengan menggunakan $\alpha=0,05$. Langkah awal dalam pengujian hipotesis adalah terkait dengan persyaratan analisis. Persyaratan yang harus dipenuhi sebelum melakukan analisis regresi dan korelasi sebagai pengujian hipotesis adalah : (1) sampel harus diacak dan memenuhi sampel minimum, (2) skor variabel untuk setiap kelompok harus berasal dari populasi yang memiliki distribusi normal, dan (3) untuk persamaan regresi harus siginifikan dan linier maka dalam penelitian ini uji persyaratan analisis yang dilakukan hanya meliputi uji normalitas, uji homogenitas dan uji linieritas.

\section{HASIL DAN PEMBAHASAN}

Responden dalam penelitian ini sebanyak 80 orang. Pengambilan data untuk uji validitas dan reliabilitas dilakukan terhadap 20 responden. Setelah dilakukan kalibrasi instrumen penelitian melalui uji validitas dan realibilitas, pengambilan data penelitian dilakukan kembali dengan menyebarkan kuesioner kepada dosen tetap Universitas Suryadarma terhadap 65 orang.

\section{Deskriptif Data}

Dalam mendeskripsikan data digunakan perhitungan deskripsi statistik meliputi: skor minimal, skor maksimal, jangkauan, rata-rata, simpangan baku dan varians.

\begin{tabular}{|c|c|c|c|c|}
\hline & \multicolumn{3}{|c|}{ Statistics } & \\
\hline & $\begin{array}{c}\text { Gaya_Kepemim } \\
\text { pinan }\end{array}$ & $\begin{array}{c}\text { Lingkungan_Ker } \\
j \mathrm{a}\end{array}$ & Kompensasi & $\begin{array}{c}\text { Komitmen_Org } \\
\text { anisasi }\end{array}$ \\
\hline Valid & 60 & 60 & 60 & 60 \\
\hline Missing & 0 & 0 & 0 & 0 \\
\hline Mean & 80,87 & 82,37 & 81,40 & 109,03 \\
\hline Std. Error of Mean & 1,017 & 1,272 & 1,331 & 1,325 \\
\hline Median & 81,00 & 82,00 & 80,00 & 108,00 \\
\hline Mode & $82^{\mathrm{a}}$ & $76^{\mathrm{a}}$ & $74^{3}$ & 108 \\
\hline Std. Deviation & 7,875 & 9,850 & 10,312 & 10,261 \\
\hline Variance & 62,016 & 97,016 & 106,346 & 105,287 \\
\hline Range & 34 & 42 & 40 & 46 \\
\hline Minimum & 64 & 62 & 62 & 86 \\
\hline Maximum & 98 & 104 & 102 & 132 \\
\hline Sum & 4852 & 4942 & 4884 & 6542 \\
\hline
\end{tabular}




\section{Pengujian Persyaratan Analisis}

Pengujian persyaratan analisis meliputi uji normalitas, uji homogenitas dan uji linieritas. Ketiga uji tersebut untuk masing-masing variabel sudah memenuhi untuk dilakukan analisis regresi linier berganda dengan tujuan meramalkan nilai pengaruh ketiga variabel bebas yaitu gaya kepemimpinan (X1), lingkungan kerja (X2) dan kompensasi (X3) terhadap variabel terikatnya yaitu komitmen organisasi (Y).

\section{Analisis Regresi Berganda}

Hasil analisis menggunakan program Statistical Package for Social Sciences (SPSS) for Windows versi 2.1 didapatkan nilai persamaan regresi linear berganda antara variabel bebas yaitu, gaya kepemimpinan (X1), lingkungan kerja (X2) dan kompensasi (X3) sedangkan variabel terikat yaitu nilai dari komitmen organisasi (Y). Adapun nilai-nilai dari koefisien masing-masing variabel tersaji pada tabel di bawah ini :

Tabel 4.11 Coefficients

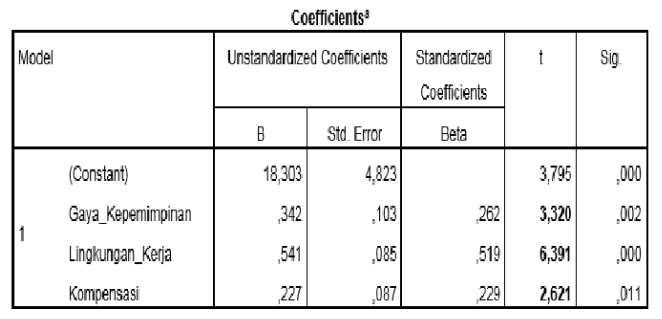

a. Dependent Variable: Kanitmen__rganisas
Dari tabel koefisien tersebut di atas, maka nilai persamaan regresi linier berganda dapat dituliskan sebagai berikut :

$\mathrm{Y}=\mathrm{a}+\mathrm{b}_{1} \mathrm{X}_{1}+\mathrm{b}_{2} \mathrm{X}_{2}+\mathrm{b}_{3} \mathrm{X}_{3}$

$\mathrm{Y}=18,303+0,342 \mathrm{X}_{1}+0,541 \mathrm{X}_{2}+0,227 \mathrm{X}_{3}$

Berdasarkan persamaan regresi di atas menunjukkan bahwa, besarnya nilai dari masing-masing variabel bebas, yaitu variabel gaya kepemimpinan (X1), lingkungan kerja (X2) dan kompensasi (X3) nilainya adalah positif. Hal ini berarti bahwa variabel bebas memiliki pengaruh yang signifikan dan searah terhadap nilai komitmen organisasi. Sehingga apabila variabel-variabel bebas tersebut mengalami kenaikan, maka nilai variabel terikat juga akan mengalami kenaikan, begitu juga sebaliknya.

Hubungan pengaruh tiga variabel bebas secara bersama-sama terhadap variabel terikat berdasarkan hasil output pengolahan data dengan menggunakan SPSS adalah sebagai berikut :

Tabel 4. Model Summary

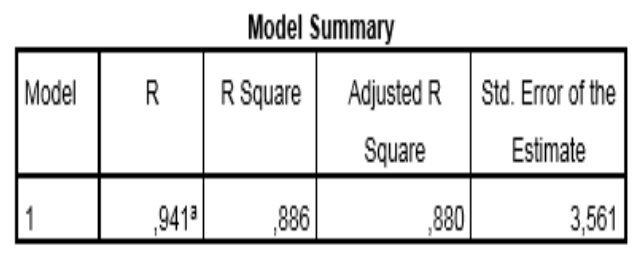

a. Predictors: (Constant), Kompensasi, Gaya_Kepemimpinan,

Lingkungan_Kerja 
Berdasarkan tabel di atas diketahui bahwa nilai koefisien korelasi berganda (R) sebesar 0,941 yang berarti hubungan variabel gaya kepemimpinan (X1), lingkungan kerja (X2) dan kompensasi (X3) dengan variabel komitmen organisasi $(\mathrm{Y})$ menunjukkan hubungan atau korelasi yang sangat kuat dan positif.

Sedangkan besarnya koefisien determinasi atau R Square sebesar 0,886 . Hal ini menunjukkan $88,6 \%$ variabel komitmen organisasi (Y) dipengaruhi atau dijelaskan oleh faktor variabel gaya kepemimpinan (X1), lingkungan kerja (X2) dan kompensasi (X3) sedangkan sisanya sebesar $11,4 \%$ ditentukan oleh faktorfaktor lain, yang dalam penelitian ini tidak dapat diteliti oleh peneliti.

\section{Pengujian Hipotesis Penelitian}

Hipotesis Parsial
a. Pengaruh Gaya Kepemimpinan terhadap Komitmen Organisasi.

Dari hasil perhitungan uji $\mathrm{t}$ diperoleh $\mathrm{t}_{\text {hitung }}$ sebesar 3,320 sedangkan harga $t_{\text {tabel }}$ pada taraf signifikan 0,005 dengan derajat kebebasan (df) 60 yaitu sebesar 2,000. Dengan demikian, dapat diketahui bahwa nilai $t_{\text {hitung }}>t_{\text {tabel }}$ maka $\mathrm{H}_{1}$ diterima dan $\mathrm{H}_{0}$ ditolak, artinya: Gaya Kepemimpinan berpengaruh positif dan signifikan terhadap Komitmen Organisasi Dosen di Universitas Suryadarma, Jakarta.

b. Pengaruh Lingkungan Kerja terhadap Komitmen Organisasi
Dari hasil perhitungan uji $\mathrm{t}$ diperoleh $\mathrm{t}_{\mathrm{hitung}}$ sebesar 6,391 sedangkan harga $t_{\text {tabel }}$ pada taraf signifikan 0,005 dengan derajat kebebasan (df) 60 yaitu sebesar 2,000. Dengan demikian, dapat diketahui bahwa nilai $t_{\text {hitung }}>\mathrm{t}_{\text {tabel }}$ maka $\mathrm{H}_{1}$ diterima dan $\mathrm{H}_{0}$ ditolak, artinya : Lingkungan Kerja berpengaruh positif dan signifikan terhadap Komitmen Organisasi Dosen di Universitas Suryadarma di Jakarta.

\section{c. Pengaruh Kompensasi terhadap Komitmen Organisasi}

Dari hasil perhitungan uji $\mathrm{t}$ diperoleh $\mathrm{t}_{\text {hitung }}$ sebesar 2,621 sedangkan harga $t_{\text {tabel }}$ pada taraf signifikan 0,005 dengan derajat kebebasan (df) 60 yaitu sebesar 2,000. Dengan demikian, dapat diketahui bahwa nilai $t_{\text {hitung }}>t_{\text {tabel }}$ maka $\mathrm{H}_{1}$ diterima dan $\mathrm{H}_{0}$ ditolak, artinya : Kompensasi berpengaruh positif dan signifikan terhadap Komitmen Organisasi Dosen di Universitas Suryadarma di Jakarta.

Hipotesis Simultan

Pengujian hipotesis statistik untuk simultan dengan menggunakan uji F. Uji F bertujuan untuk menguji signifikansi model regresi variabel gaya kepemimpinan (X1), lingkungan kerja (X2) dan kompensasi (X3) secara bersama-sama terhadap komitmen organisasi (Y). Hasil uji $\mathrm{F}$ seperti yang terdapat pada tabel berikut : 
Tabel 4. Anova

\begin{tabular}{|c|c|c|c|c|c|c|}
\hline \multicolumn{7}{|c|}{ ANOVA } \\
\hline Mod & & Sum of Squares & df & Mean Square & $\mathrm{F}$ & Sig. \\
\hline \multirow{3}{*}{1} & Regression & 5502,002 & 3 & 1834,001 & 144,667 &, $000^{b}$ \\
\hline & Residual & 709,932 & 56 & 12,677 & & \\
\hline & Total & 6211,933 & 59 & & & \\
\hline
\end{tabular}

a. Dependent Variable: Komitmen_Organisasi

b. Predictors: (Constant), Kompensasi, Gaya_Kepemimpinan, Lingkungan_Kerja

Berdasarkan tabel diatas, diperoleh $\mathrm{F}$ hitung sebesar 144,667 sedangkan harga kritis nilai $\mathrm{F}$ tabel pada $\alpha(0,05)$ derajat bebas pembilang 3 dan penyebut 56 pada $\alpha$ $(0,05)$ yaitu sebesar 2,77. Hal ini menunjukan bahwa nilai $\mathrm{F}_{\text {hitung }}>\mathrm{F}_{\text {tabel }}$ maka $\mathrm{H}_{1}$ diterima dan $\mathrm{H}_{0}$ ditolak, artinya Gaya Kepemimpinan, Lingkungan Kerja dan Kompensasi secara simultan berpengaruh positif dan signifikan terhadap Komitmen Organisasi Dosen di Universitas Suryadarma, Jakarta.

Kerangka kausal empiris antara jalur $\mathrm{X}_{1}$ terhadap $\mathrm{Y}, \mathrm{X}_{2}$ terhadap $\mathrm{Y}, \mathrm{X}_{3}$ terhadap $\mathrm{Y}$ dapat dibuat melalui persamaan struktural sebagai berikut :

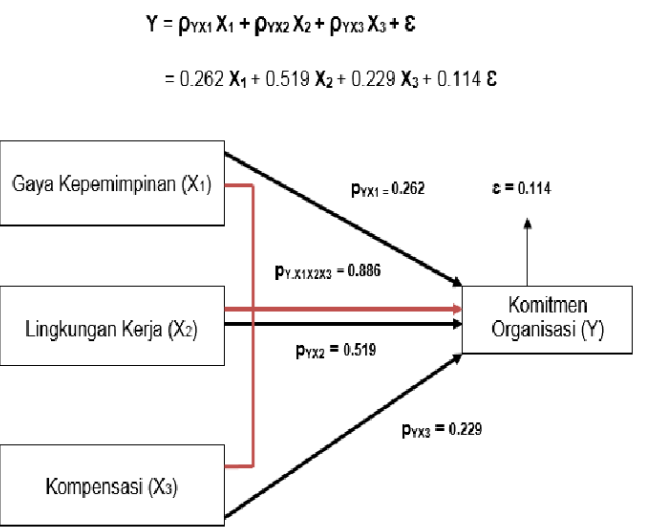

Gambar 4| Struktur Kausal $X_{1}, X_{2}, X_{3}$ terhadap $Y$

Hasil temuan penelitian di atas dapat diringkas seperti tabel sebagai berikut :
Tabel 4. Ringkasan Nilai Koefisien Jalur

\begin{tabular}{|c|c|c|c|c|}
\hline \multirow{2}{*}{ Variabel } & \multirow{2}{*}{$\begin{array}{c}\text { Koefisien } \\
\text { Jalur }\end{array}$} & \multicolumn{2}{|c|}{ Pengaruh } & Kontribusi \\
\cline { 3 - 4 } & & Langsung & Total & Simultan \\
\hline $\mathrm{X}_{1}$ & 0.262 & 0.262 & $6.86 \%$ & - \\
\hline $\mathrm{X}_{2}$ & 0.519 & 0.519 & $26.9 \%$ & - \\
\hline $\mathrm{X}_{3}$ & 0.229 & 0.229 & $5.24 \%$ & - \\
\hline$\varepsilon$ & 0.114 & 0.114 & $11.4 \%$ & - \\
\hline $\mathrm{X}_{1}, \mathrm{X}_{2}, \mathrm{X}_{3}$ & - & - & - & $0.886=88.6 \%$ \\
\hline
\end{tabular}

\section{KESIMPULAN DAN SARAN}

\section{Kesimpulan}

Berdasarkan hasil penelitian dan analisis data yang telah dilakukan maka dapat diambil kesimpulan sebagai berikut :

1. Komitmen organisasi dipengaruhi langsung positif dan signifikan oleh gaya kepemimpinan. Ini berarti peningkatan kualitas gaya kepemimpinan yang berpihak pada kepentingan organisasi mengakibatkan peningkatan komitmen organisasi pada dosen Unsurya.

2. Komitmen Organisasi dipengaruhi langsung positif dan signifikan oleh lingkungan kerja. Ini berarti peningkatan lingkungan kerja yang harmonis dan kondusif mengakibatkan peningkatan komitmen organisasi pada dosen Unsurya.

3. Komitmen Organsasi dipengaruhi langsung positif dan signifikan oleh kompensasi. Ini berarti peningkatan kompensasi yang diberikan organisasi mengakibatkan peningkatan komitmen dalam berorganisasi pada dosen di Universitas suryadarma. 
4. Komitmen Organisasi dipengaruhi langsung dan signifikan juga secara simultan oleh ketiga variabel yaitu gaya kepemimpinan, lingkungan kerja dan kompensasi. Ini berarti peningkatan ketiga variabel tersebut secara bersamaan dapat mengakibatkan peningkatan komitmen organisasi pada dosen Unsurya.

\section{Saran}

Berdasarkan kesimpulan penelitian disarankan berbagai upaya yang dapat dilakukan dalam rangka meningkatkan komitmen organisasi dosen di Universitas Suryadarma, Jakarta.

(1) Universitas Suryadarma dapat meningkatan mutu pendidikan dengan pemberian beasiswa bagi dosen yang berprestasi untuk melanjutkan ke jenjang pendidikan yang lebih tinggi, meningkatkan gairah dosen membuat penelitianpenelitian, karya-karya ilmiah maupun aktif mengikuti kegiatan seminar-seminar dan pengabdian masyarakat lainnya dengan sepenuhnya dibiayai oleh lembaga serta dapat memfasilitasi dosen untuk membuat jabatan fungsional akademiknya sebagai bentuk pengakuan atas kemampuan akademik dalam kehidupan akedemiknya.

(2) Universitas Suryadarma dapat mengembangkan dan mensosialisasikan lingkungan kerja yang sesuai dengan norma-norma berlaku pada para dosen di lingkungan Universitas Suryadarma sehingga dengan begitu komitmen para dosen semakin meningkat.

(3) Universitas Suryadarma dapat mengembangkan dan mensosialisasikan kompensasi yang dapat meningkatkan komitmen organisasi para dosennya.

\section{DAFTAR PUSTAKA}

Campling, John, David Poole, Retha Wiesner and John R. Schermerhorn. 2002. Management. John Wiley \& Sons Australia, Ltd, New York.

Ivancevich, John M., Robert Konopaske and Michael T. Matteson. 2008. Organizational Behavior and Management, Mc Graw-Hill, New York.

Kinicki dan William. 2009. Management. Mc Graw-Hill, New York.

Rivai, Veithzal dan Ella Jauvani Segala. 2009. Manajemen Sumber Daya Manusia Untuk Perusahaan ; Dari Teori ke Praktik, PT. Raja Grafindo Persada, Jakarta, 2009

Robbins, Stephen P., Organizational Behavior. 2007. Pearson Education, Inc, Upper River, New Jersey, 2007.

Sugiyono. 2010. Statistik Untuk Penelitian. Alfabeta, Bandung.

Suma'mur PK. 1996. Higene Perusahaan dan Kesehatan Kerja. Gunung Agung, Jakarta. 
Thoha, Miftah. 2000. Pendekatan Organisasi : Konsep Dasar dan Aplikasinya. PT. Raja Grafindo Persada, Jakarta.

Undang-undang Republik Inonesia Nomor 14 Tahun 2005 tentang Guru dan Dosen 